\title{
Edaphic Arthropods in Fragment of Riparian Forest in the Semi-Arid of Paraíba
}

\author{
César Henrique Alves Borges ${ }^{1}$, Jacob Silva Souto ${ }^{2}$, Ane Cristine Fortes da Silva ${ }^{3}$, Lyanne dos Santos Alencar ${ }^{1}$, \\ Manoella de Queiroz Rodrigues Limeira ${ }^{4}$, Adriano Castelo dos Santos ${ }^{1}$, \\ Lauter Silva Souto 5 \& Patrícia Carneiro Souto ${ }^{2}$ \\ ${ }^{1}$ Forest Science Department, Federal Rural University of Pernambuco, Recife, PE, Brazil \\ ${ }^{2}$ Forest Engineering Academic Unit, Federal University of Campina Grande, Patos, PB, Brazil \\ ${ }^{3}$ Federal Institute of Education, Science and Technology of Paraíba, Princesa Isabel, Brazil \\ ${ }^{4}$ Department of Botany, Federal Rural University of Pernambuco, Recife, Brazil \\ ${ }^{5}$ Academic Unit of Agronomy, Federal University of Campina Grande, Pombal, PB, Brazil \\ Correspondence: César Henrique Alves Borges, Federal Rural University of Pernambuco, Recife, Pernambuco, \\ Brazil. E-mail: cesarhenrique27@yahoo.com.br
}

Received: October 10, 2018

Accepted: November 20, 2018 Online Published: January 15, 2019

doi:10.5539/jas.v11n2p236

URL: https://doi.org/10.5539/jas.v11n2p236

\begin{abstract}
Important for soil quality, the edaphic fauna is indicative of an environment in equilibrium. The study aimed to identify the macrofauna and mesofauna organisms of the soil in a fragment of riparian forest. The work was carried out in a fragment of ciliary forest on the farm Tamanduá, municipality of Santa Terezinha, Paraíba. The macrofauna was quantified in soil samples collected at different depths $(0-5 \mathrm{~cm}$ and $5-10 \mathrm{~cm})$ using the TSBF method. For the mesofauna was collected randomly in the same area, samples of soil + litter in the depths $0-5 \mathrm{~cm}$ and 5-10 cm using metal rings. The design was completely randomized in a $4 \times 2$ factorial scheme $(4$ seasons, 2 depths), with 5 replicates, the means being compared by the Tukey test. The main orders of the macrofauna were: Hymenoptera, Coleoptera, Isoptera, and Enquitreídeos being the order of greater proportion in the two depths to Hymenoptera. There were a higher population and diversity of soil macrofauna in the superficial layer $(0-5 \mathrm{~cm})$. For the mesofauna were found in the samples organisms belonging to the groups Acarina and Collembola, being the order Acarina the most representative in the two depths evaluated. The environment of riparian forest presents greater diversity and density of macrofauna and mesofauna of the soil in the layer of $0.0-5.0 \mathrm{~cm}$ of depth, which presents greater food supply and conditions favorable to the survival of these organisms.
\end{abstract}

Keywords: invertebrates of soil, TSBF method, riparian environment

\section{Introduction}

In the riparian forests, there is a higher number and diversity of plant species, than is generally found in nearby areas. Therefore they play an essential role between the aquatic and terrestrial environments, as they contribute to soil fixation, decrease the exposure of the beds to the wind and consequently the excess evaporation. Riparian zones are considered a refuge for fauna diversity, especially in semi-arid regions that experience long periods of drought (Lima, 2009). These environments are also crucial for edaphic fauna, sheltering them and protecting them from high temperatures, solar radiation, and low soil moisture.

The preferred location of edaphic soil fauna in the superficial layers in the different environments is mainly due to the contribution of litter to the fact that these organisms provide favorable oxygen conditions and greater availability of food, thus favoring a greater proliferation of this community. It acts on the physical and chemical improvements of the soil where they are (Borges et al., 2016).

There are several ways to classify the organisms present in the soil, such as body size, mobility, eating habits, and soil functions. However, the most commonly used classifications involve the separation of organisms according to their diameter or length.

The soil fauna is classified according to its size in different groups: microfauna $<0.2 \mathrm{~mm}$, represented by nematodes and protozoa, mesofauna ranging from 0.2 to $2.0 \mathrm{~mm}$ and macrofauna $>2.0 \mathrm{~mm}$ (Melo et al., 2009). 
The soil fauna is very important for the forest and agricultural soil, improving its physical, chemical and biological attributes, important mainly in the dynamics of the organic matter and the return of nutrients to the soil, since the organisms act of direct form in the trituration of the litter deposited in the soil surface, causing a rapid incorporation of this material into the soil and mineralization of the nutrients.

The composition of the edaphic fauna is associated with several biological factors that interact with each other and are sensitive to edaphoclimatic conditions (Korasaki et al., 2013). This group of elements directly affects soil organisms, resulting in different populations, depending on soil type, vegetation and microclimatic conditions (Berude et al., 2015).

Considering the lack of information in the Paraíba Semi-arid, the study aimed to identify the macrofauna and mesofauna organisms of the soil in a fragment of ciliary forest.

\section{Method}

The study was carried out in a fragment of ciliary forest located on the banks of the Conceição Creek $\left(07^{\circ} 00^{\prime} 30^{\prime \prime}\right.$ S and $37^{\circ} 23^{\prime} 37.7^{\prime \prime} \mathrm{W}$ ), belonging to Fazenda Tamanduá, municipality of Santa Teresinha, Paraíba. The climate of the region according to the Köppen classification is BSh (Alvares et al., 2013). The city has an average altitude of 300 meters and its rainfall around $600 \mathrm{~mm}$.

The soil fauna community in the study area was quantified and characterized by sampling at different times, with intervals of 15 days (March to May) in the rainy season in the region. For the sampling of the macrofauna (figure 1), it was carried out by TSBF (Tropical Soil Biology and Fertility), described by Anderson and Ingram (1993), modified. The dimensions of the monolith were $25.0 \mathrm{~cm} \times 15.0 \mathrm{~cm} \times 10.0 \mathrm{~cm}$.
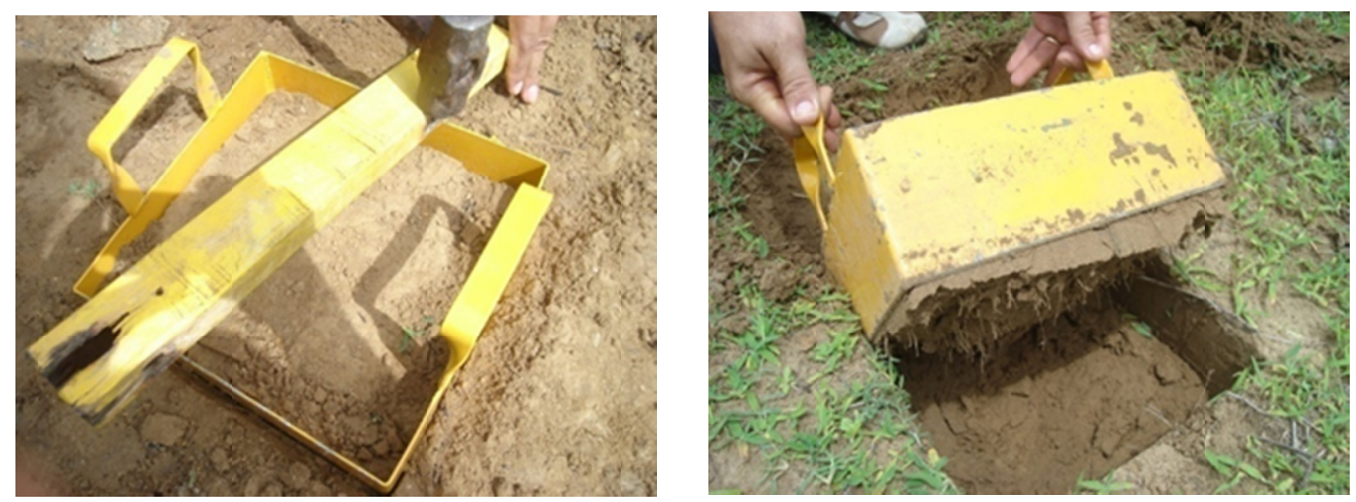

Figure 1. Collection of the edaphic macrofauna in a metallic frame in a Riparian Forest fragment in the Semi-arid of Paraíba

The samples were randomly collected at two depths: $0-5 \mathrm{~cm}$ and 5-10 cm, with five, replicates each, totaling 10 samples, which were stored in plastic bags, duly identified and later taken for classification in the LabNut (Laboratory of Mineral Nutrition of Plants) of the Federal University of Campina Grande, Patos Campus. In the laboratory, the macrofauna was screened in each sample by hand under artificial lighting, the individuals were visible to the naked eye and stored in pots, duly identified, containing $70 \%$ alcohol solution for storage and subsequent quantification and identification order.

Samples of mesofauna were also collected in the same area, with samplings being carried out randomly in the area, distance from one another in about 30 meters. Samples of soil + litter were collected in two depths $(0-5 \mathrm{~cm}$ and 5-10 cm) with five replicates each, totalizing ten samples, where they were collected with the aid of metallic rings with dimensions of $5.2 \mathrm{~cm}$ in height and $4.8 \mathrm{~cm}$ in diameter (Figure 2). 

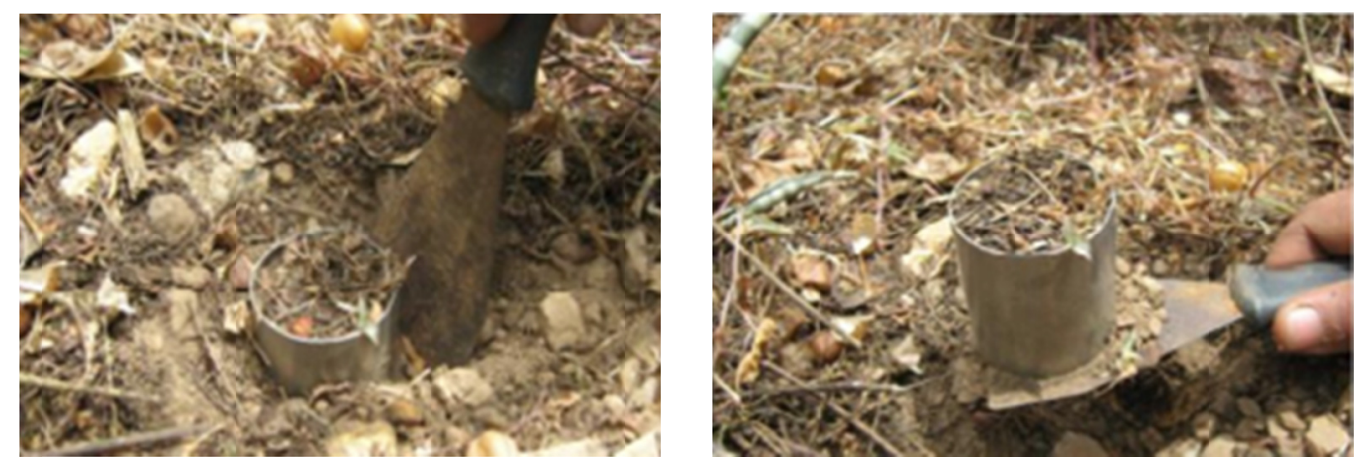

Figure 2. Collection of soil + litter samples in a fragment of Ciliary Forest in the Paraíba Semi-Arid, to extract the edaphic mesofauna using a metal ring

The specimens were identified in a Styrofoam box to minimize moisture losses and transported to LabNut, where they were placed in the modified Berlese-Tullgren apparatus for extraction of organisms (Figure 3). The rings were placed in the device were subjected to a light and heat source provided by $25 \mathrm{~W}$ lamps. With the heating of the soil sample for a period of 96 hours, the organisms present in the samples migrate to the lower layers of the rings, so as to leave the zone of intense heat, falling, later, in bottles of glass containing a solution of alcohol to $70 \%$. To direct the fall of the organisms to the solution were placed funnels in part superior of the jars.

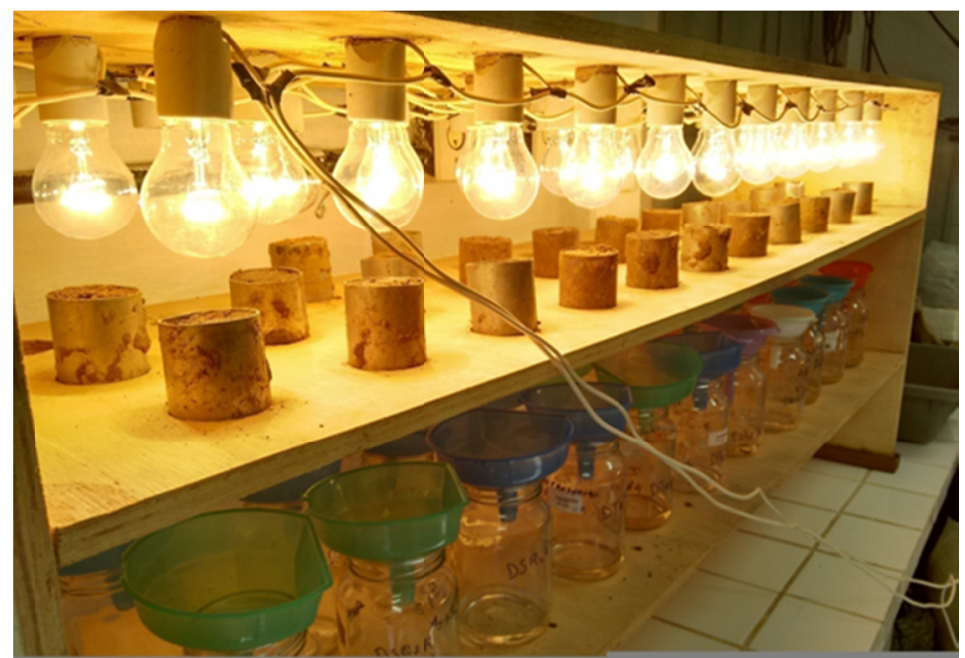

Figure 3. Rings with soil samples in the Berlese-Tullgren extractor

The organisms present in the flasks were screened with the aid of a bio-type microscope, and the individuals were identified in large taxonomic groups (Order), where the morphological characteristics were compared with the specialized literature (Triplehorn \& Johnson, 2011; Costa et al., 2006, Kingsley, 1999, Höfer \& Brescovit, 2001). The classification used for the differentiation between organisms found in the samples was that of Swift et al. (1979), who classified as organisms of the mesofauna those with a body length between $100 \mu \mathrm{m}$ and $2.0 \mathrm{~mm}$.

For the macrofauna, the ecological behavior was evaluated, the total number of individuals (abundance) was measured, and comparisons were made of the communities in the studied areas using the Shannon diversity indexes and the Pielou equitability index (U). The index of Shannon $(\mathrm{H}=\Sigma \mathrm{pi} \cdot \log \mathrm{pi}$, where, $\mathrm{pi}=\mathrm{ni} / \mathrm{N}$, where, ni = number of individuals in the group and $\mathrm{N}=\Sigma$ of all individuals), associates the wealth of organisms with the equitability between the orders to determine which treatment has the greatest diversity of orders. It assumes values that can vary from 0 to 5 , being that the decline of its values is the result of a greater dominance of groups in detriment of others (Begon et al., 1996). 
The Pielou Uniformity Index (e) is an index that represents the uniformity of the distribution of the number of individuals in the different groups in each area and varies from 0 to 1 , being calculated by the following equation: $\mathrm{e}=\mathrm{H} / \log \mathrm{S}$, where $\mathrm{H}=$ Shannon index; $\mathrm{S}=$ Number of species.

A completely randomized design, arranged in a $4 \times 2$ factorial scheme ( 4 epochs, 2 depths), with 5 replicates was used for the analysis of the edaphic fauna. The results were submitted to analysis of variance (ANOVA) to verify if there was difference between the evaluated depths. When significant differences were established, the Tukey test, at the 5\% error probability level, was applied using the statistical software Assistat Version 7.6 beta (Silva \& Azevedo, 2012).

\section{Results}

In the experimental period, a rainfall of $243.4 \mathrm{~mm}$ was recorded, with the highlight for the month of February / 2012, with $195 \mathrm{~mm}$ (Figure 4). These rainfall data were very low in previous years, where probably the significant decrease of water content in the soil interfered with the food supply, besides the microclimatic modification of the soil that stimulated the migration of organisms to deeper layers, as a survival strategy.

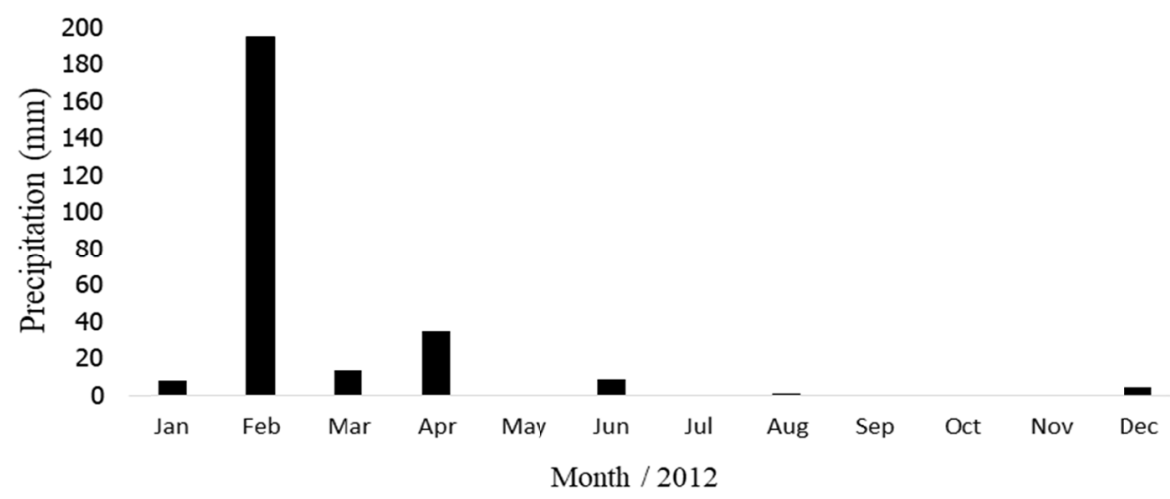

Figure 4. Average monthly rainfall during the experimental period, in the Ciliary Forest in the Paraíba semi-arid region

Observing table 1 , it is verified that only significance occurred for depth, about the organisms of the macrofauna of the soil.

Table 1. Analysis of variance of the soil macrofauna collected in Mata Ciliar in the Paraíba semi-arid region

\begin{tabular}{lllll}
\hline FV & Gl & SQ & QM & F \\
\hline Epoch (E) & 3 & 9.00 & 3.000 & $0.3015^{\text {ns }}$ \\
Depth (D) & 1 & 78.40 & 78.4000 & $7.8794^{* *}$ \\
E $\times$ D & 3 & 3.80 & 1.2667 & $0.1273^{\text {ns }}$ \\
Treatment & 7 & 91.20 & 13.02857 & $1.3094^{\text {ns }}$ \\
Residue & 32 & 318.40 & 9.9500 & \\
\hline Total & 39 & & & \\
\hline
\end{tabular}

Note. ${ }^{* *}$ Significant at $1 \%$ probability; $\mathrm{ns}=$ not significant.

When analyzing the depth of collection (Table 2), there is a significant difference between the number of individuals collected in the $0-5 \mathrm{~cm}$ layer (P1) and those collected in the depth $5-10 \mathrm{~cm}(\mathrm{P} 2)$. This higher number of individuals in the $0-5 \mathrm{~cm}$ layer is due mainly to higher soil moisture and to higher organic matter content in the superficial layers.

Table 2. Average number of macrofauna organism collected at different depths in soil under Ciliary forest in the Paraíba semi-arid region

\begin{tabular}{ll}
\hline Depth $(\mathrm{P})$ & Number of organisms \\
\hline P1 $(0-5 \mathrm{~cm})$ & $6.8 \mathrm{a}$ \\
P2 $(5-10 \mathrm{~cm})$ & $4.0 \mathrm{~b}$ \\
\hline
\end{tabular}


Quantifying the macrofauna organisms of the soil in Ciliary Mata area, a total of 210 individuals were observed, distributed in 14 taxonomic groups (Table 3), and 133 were present in the soil collected at depth $0-5 \mathrm{~cm}$ and, 77 in the layer of $5-10 \mathrm{~cm}$.

Table 3. Abundance and relative frequency of soil macrofauna individuals found in different depths in the Ciliary Mata area in the Paraíba semi-arid region

\begin{tabular}{lllll}
\hline \multirow{2}{*}{ Orders } & \multicolumn{2}{c}{ Depth } & \multirow{2}{*}{ Total } & \multirow{2}{*}{ RF $(\%)^{*}$} \\
\cline { 2 - 3 } Hymenoptera & $0-5 \mathrm{~cm}$ & $5-10 \mathrm{~cm}$ & 46 & 21.90 \\
Orthoptera & 23 & 23 & 3 & 1.43 \\
Aranea & 3 & 0 & 11 & 5.24 \\
Coleoptera & 8 & 3 & 15 & 7.14 \\
Isoptera & 12 & 3 & 36 & 17.14 \\
Blattodea & 23 & 13 & 4 & 1.90 \\
Spirobolida & 1 & 3 & 16 & 7.62 \\
Dermaptera & 9 & 7 & 2 & 0.95 \\
Thysanura & 2 & 0 & 1 & 0.5 \\
Larva de Coleoptera & 0 & 1 & 41 & 19.50 \\
Enquitreídeo & 26 & 15 & 25 & 11.90 \\
Odonata (ninfa) & 22 & 3 & 7 & 3.33 \\
Hemiptera & 1 & 6 & 2 & 0.95 \\
Thysanoptera & 2 & 0 & 1 & 0.5 \\
Total & 1 & 0 & 210 & 100.00 \\
\hline
\end{tabular}

Note. ${ }^{*} \mathrm{RF}=$ Relative frequency.

The order Hymenoptera presented the highest relative frequency with $21.9 \%$. Of the individuals collected in the 0-5 cm layer (71\%) belong to four orders (Larva of Coleoptera, Hymenoptera, Isoptera, and Enquitreídeos), already in the layer of $5-10 \mathrm{~cm}$ the orders that predominated were Hymenoptera, Isoptera and Larva of Coleoptera.

Analyzing the Shannon Index (Table 4), it is possible to affirm that there is a greater diversity of macrofauna individuals in the first five centimeters of depth.

Table 4. Shannon $(\mathrm{H})$ and Pielou (e) index at depths of 0-5 $\mathrm{cm}$ and 5-10 $\mathrm{cm}$, for macrofauna in Ciliary Mata organisms in the Paraíba semi-arid

\begin{tabular}{lll}
\hline Depth & $\mathrm{H}$ & $\mathrm{E}$ \\
\hline $0.0-5.0$ & 1.114078175 & 0.432296 \\
$5.0-10.0$ & 1.958912734 & 0.450967 \\
\hline
\end{tabular}

The Pielou Equability Index (e), which indicates whether the species are equally abundant, presented similar values for both at depths. The large number of individuals of Coleoptera-larva, Hymenoptera, Isoptera and Enquitreídeos for the first five $\mathrm{cm}$, and of Hymenoptera, Isoptera and Coleoptera-larva for the range of 5.0 to $10.0 \mathrm{~cm}$, reduce the equitability.

In relation to the mesofauna groups, it is observed in Figure 5 that only two groups, Acarina and Collembola, were found in the soil samples + litter, and the order Acarina was the most representative in the two depths evaluated. 

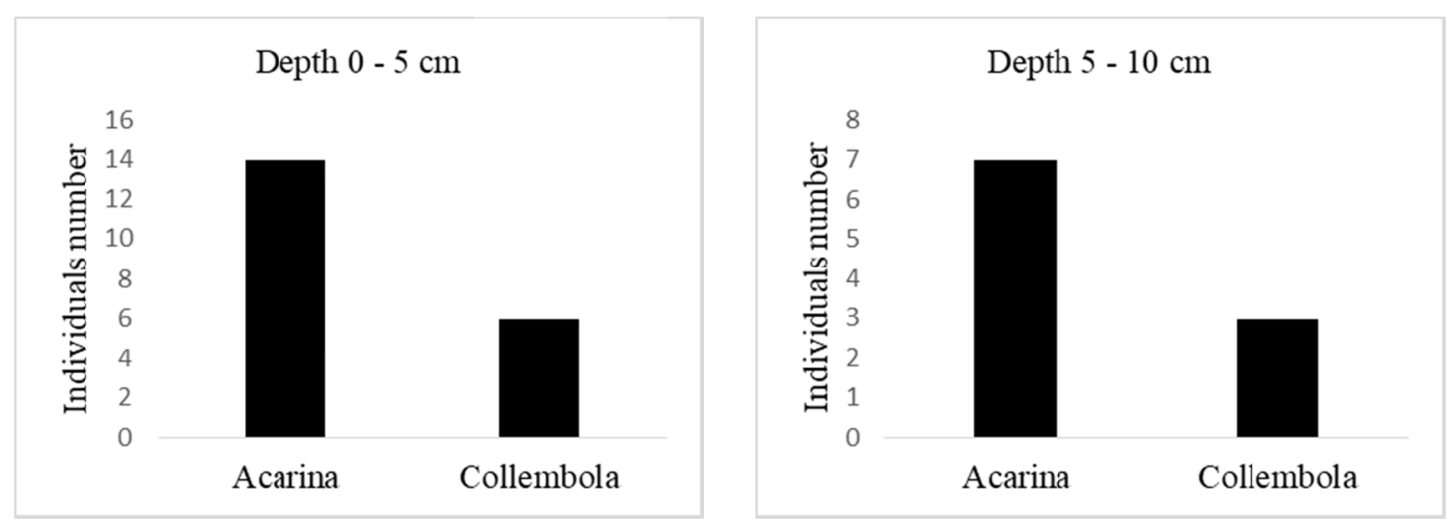

Figure 5. Number of individuals from the orders Acarina and Collembola collected at depths $0-5 \mathrm{~cm}$ and 5-10 cm, in a riparian forest area in the semi-arid region of Paraiba

\section{Discussion}

These conditions, such as vegetation cover and humidity, provide a mosaic of microclimatic conditions, resulting in the creation of several microclimates that guarantee the permanence of local biodiversity (Moço et al., 2005).

Garcia and Catanozi (2011), when characterizing the edaphic fauna community in different levels of soil in conserved areas of Atlantic Forest and reforestation with Pinus sp., in the city of São Paulo also observed greater diversity, density, and group richness surface. In the area with reforestation with Pinus sp, they also verified that only the layer closest to the soil surface $(0.0-0.1 \mathrm{~m})$ presented diversity, density, and richness of groups significantly higher than in relation to the other extracts. For the authors, these results demonstrate that, in a few centimeters deep, there are environmental factors that motivate important changes in the distribution of macrofauna organisms.

Cruz et al. (2015) evaluating the organisms of the macrofauna of the soil in Legal Reserve area in the state of Paraíba, also detected that the most abundant groups corresponded to the orders Hymenoptera and Coleoptera.

The order Hymenoptera presented the highest relative frequency with $21.9 \%$. Araújo et al. (2010) also recorded a higher frequency of this order when estimating the interval proportion of the diversity of invertebrates found in the soil in different locations in Ituiutaba, MG. Brancher and Roza-Gomes (2012) also observed the predominance of the order Hymenoptera, with $51 \%$ of all the individuals captured, when surveying the edaphic fauna in a fragment of mixed ombrophilous transition forest for deciduous seasonal forest, in the municipality of Anchieta, Santa Catherine.

The fact that the ants respond for much of the fauna of the soil in the two depths was already expected. According to Alves et al. (2014), they have significant resistance to the variations that occur in the environment, and may explain their predominance in forest fragments where several studies of diversity cite these animals as the most abundant in these ecosystems (Maestri et al., 2013; Zardo et al., 2010).

The importance of studying the macrofauna population at different depths is due to the fact that changes in the environment considerably affect the balance in the population. Garcia and Catanozi (2011) point out that soil depth is a relevant factor in the study of ecological variables such as the density of organisms, group richness, and diversity index, reinforcing the need for the conservation of native forest environments.

Different results were obtained by Cândido et al. (2012), these authors evaluated the soil and litter macrofauna population of a demonstration unit of ecological restoration and an area of ciliary forest, and observed that the order Coleoptera had greater relative abundance, except for the sample of ciliary forest with litter.

Comparing the Shannon diversity index of a riparian forest area and an ecological restoration demonstration unit, Cândido et al. (2012) verified that there is greater diversity for the first one. This can be explained by the greater heterogeneity of the vegetation cover of the riparian forest, providing greater macrofauna diversity and soil support capacity (Marques et al., 2014).

Based on the results of the work carried out by Marques et al. (2014), it is possible to observe that the Pielou Index for the macrofauna population of the soil (without litter) of riparian forest in the summer found by these authors was slightly smaller than those found in this study. The authors justify that the low values are influenced 
by $81 \%$ of the soil organisms in the forest being concentrated within a taxonomic group, the order Oligochaeta, which reduces the biodiversity index $\left(\mathrm{H}^{\prime}\right)$ and consequently less equitability $\left(\mathrm{J}^{\prime}\right)$.

The abundance of the Collembola group is associated with its ability to multiply and grow rapidly (Antoniolli et al., 2013). This group is best developed in environments of native vegetation, where conditions such as plant species varieties and organic soil compounds allow a greater diversity of soil organisms (Rief et al., 2010).

\section{References}

Alvares, C. A., Stape, J. L., Sentelhas, P. C., Gonçalves, J. L. M., \& Sparovek, G. (2013). Köppen’s climate classification map for Brazil. Meteorologische Zeitschrift, 22(6), 711-728. https://doi-org10.1127/09412948/2013/0507

Alves, F. A. L., Alves, C. A. B., Alves, P. R. R., Oliveira, R., Josa, J. H., Fernandes, Y. T. D., Nunes, E. N., \& Souto, J. C. (2014). Caracterização da maco e mesofauna edáfica sobre um fragmento remanescente de "mata atlântica" em Areia-PB. Gaia Scientia, 2(1), 384-391.

Anderson, J. M., \& Ingram, J. S. I. (1993). Soil fauna. Tropical soil biological and fertility: A handbook of methods (2nd ed., pp. 44-46). Wallingford: C.A.B. International.

Antoniolli, Z. I., Redin, M., Souza, E. L., \& Pocojeski, E. (2013). Metais pesados, agrotóxicos e combustíveis: Efeito na população de colêmbolos no solo. Revista Ciência Rural, 43(6), 992-998. https://doi.org/10.1590/ S0103-84782013005000056

Araújo, C. C., Nomelini, Q. S. S., Pereira, J. M., Liporacci, H. S. M., \& Kataguiri, V. S. (2010). Comparação da abundância de invertebrados de solo por meio da estimação intervalar encontrados em diferentes ambientes na cidade de Ituiutaba-MG. Bioscience Journal, 26(5), 817-823.

Brancher, D., \& Roza-Gomes, M. F. (2012). Suvery of edaphic fauna in forest fragmente in the munipality of Anchieta (SC, Brazil). Biota Neutropica, 12(3), 1-4. https://doi.org/10.1590/S1676-06032012000300010

Borges, C. H. A., Souto, P. C., Costa, R. M. C., Novais, D. B., Souto, J. S., \& Barroso, R. F. (2016). Artrópodes edáficos em fragmentos de floresta ombrófila aberta na Paraíba, Brasil. Revista Verde de Agroecologia e Desenvolvimento Sustentável, 11(2) 26-32. https://doi.org/10.18378/rvads.v11i2.4212

Cândido, A. K. A. A., Silva, N. M., Barbosa, D. S., Farias, L. N., \& Souza, W. P. (2012). Fauna edáfica como bioindicadores de qualidade ambiental na nascente do Rio São Lourenço, Campo Verde-MT, Brasil. Engenharia Ambiental, 9(1) 67-82.

Costa, C., Ide, S., \& Simonka, C. E. (2006). Insetos imaturos: Metamorfose e identificação (p. 249). Ribeirão Preto: Holos.

Cruz, M. P., Cruz, K. R. P., Souza, J. T. A., \& Bezerra, C. V. de C. (2015). Caracterização da Macrofauna Artrópoda em Área de Reserva Florestal no Município de Lagoa Seca-Paraíba. Cadernos de Agroecologia, $10(2), 1-4$.

Garcia, D. V. B., \& Catanozi, G. (2011). Análise de macrofauna d solo em área de Mata Atlântica e de reflorestamento com Pinus sp.-zona sul de São Paulo. Revista Ibirapuera, 2, 10-14.

Höfer, H., \& Brescovit, A. D. (2001). Species and guild structure of a Neotropical spider assemblage (Araneae) from Reserva Ducke, Amazonas, Brazil. Andrias, 15, 99-119.

Kingsley, R. (1999). Aranhas-Guia prático (p. 64). NBL Editora: São Paulo.

Maestri, R., Leite, M. A. S., Schmitt, L. Z., \& Restello, R. M. (2013). Efeito da mata nativa e bosque de eucalipto sobre a riqueza de artrópodos na serapilheira. Perspectiva, 37(Edição Especial), 31-40.

Marques, D. M., Silva, A. B., Silva, L. M., Moreira, E. A., \& Pinto, G. S. (2014). Macrofauna edáfica em diferentes coberturas vegetais. Biocinese Journal, 30(5), 1588-1597.

Melo, F. V., Brown, G. G., Constantino, R., Louzada, J. N. C., Luizão, F. J., Morais, J. W., \& Zanetti, R. (2009). A importância da meso e macrofauna do solo na fertilidade e como bioindicadores. Boletim Informativo da SBCS, 1, 38-42.

Moço, M. K. S., Gama-Rodrigues, E. F., Gama-Rodrigues, A. C., \& Correia, M. E. F. (2005). Caracterização da Fauna Edáfica em Diferentes Coberturas Vegetais na Região Norte Fluminense. Revista Brasileira de Ciência do Solo, 29(4), 555-564. https://doi.org/10.1590/S0100-06832005000400008

Ribeiro-Costa, C. S., \& Rocha, R. M. (2006). Invertebrados: Manual de aulas práticas (p. 271). Ribeirão Preto: Holos. 
Rieff, G. G., Machado, R. G., Stroschein, M. R. D., \& Saccol de Sá, E. L. (2010). Diversidade de ácaros e colêmbolos edáficos e cultivo de Eucalipto e áreas nativas. Revista Brasileira de Agrociência, 16(1), 57-61.

Triplehorn, C. A., \& Johnson, N. F. (2011). O estudo dos insetos (p. 809). São Paulo: Cengage Learning.

Silva, F. A. S. E., \& Azevedo, C. A. V. (2012). Software de assistência a estatística (Versão Beta 7.6).

Swift, M. J., Heal, O. W., \& Anderson, J. M. (1979). Decomposition in terrestrial ecosystems (pp. 66-117). Berkeley: University of California Press.

Zardo, D. C., Carneiro, A. P., Lima, L. G., \& Santos-Filho, M. (2010). Comunidade de artrópodes associada à serrapilheira de cerrado e de mata de galeria, na estação ecológica serra das araras-Mato Grosso do Sul, Brasil. Revista Uniara, 13(2), 105-113. https://doi.org/10.25061/2527-2675/ReBraM/2010.v13i2.143

\section{Copyrights}

Copyright for this article is retained by the author(s), with first publication rights granted to the journal.

This is an open-access article distributed under the terms and conditions of the Creative Commons Attribution license (http://creativecommons.org/licenses/by/4.0/). 